\title{
Alleviation of Plant Stress Precedes Termination of Rich Fen Stages in Peat Profiles of Lowland Mires
}

\author{
Ewa Jabłońska, ${ }^{1 *}$ Dierk Michaelis, ${ }^{2}$ Marlena Tokarska, ${ }^{1}$ Klara Goldstein, ${ }^{1}$ \\ Mateusz Grygoruk, ${ }^{3}$ Mateusz Wilk, ${ }^{1}$ Tomasz Wyszomirski, ${ }^{1}$ and \\ Wiktor Kotowski ${ }^{1}$
}

\begin{abstract}
${ }^{1}$ Biological and Chemical Research Centre, Faculty of Biology, University of Warsaw, Żwirki i Wigury 101, 02-089 Warsaw, Poland; ${ }^{2}$ Institute of Botany and Landscape Ecology, University of Greifswald, Soldmannstraße 15, 17487 Greifswald, Germany; ${ }^{3}$ Faculty of Civil and Environmental Engineering, Warsaw University of Life Sciences, Nowoursynowska 159, 02-776 Warsaw, Poland
\end{abstract}

\begin{abstract}
Mesotrophic rich fens, that is, groundwater-fed mires, may be long-lasting, as well as transient ecosystems, displaced in time by poor fens, bogs, forests or eutrophic reeds. We hypothesized that fen stability is controlled by plant stress caused by waterlogging with calcium-rich and nutrient-poor groundwater, which limits expansion of hummock mosses, tussock sedges and trees. We analysed 32 European Holocene macrofossil profiles of rich fens using plant functional traits (PFTs) which indicate the level of plant stress in the environment: canopy height, clonal spread, diaspore mass, specific leaf area, leaf dry matter content, Ellenberg moisture value, hummock-forming ability, mycorrhizal status and plant functional groups. Six PFTs, which formed long-term significant trends during mire development, were compiled as rich fen stress indicator (RFSI). We found that RFSI values at the
\end{abstract}

Received 15 October 2018; accepted 16 August 2019;

published online 16 September 2019

Electronic supplementary material: The online version of this article (https://doi.org/10.1007/s10021-019-00437-y) contains supplementary material, which is available to authorized users.

Authors Contributions EJ, WK, MG, KG and TW conceived the ideas and designed the methodology; MT, DM and EJ collected the data from peat profiles; KG collected the data on plant functional traits, MW collected the data on mycorrhizal status; EJ analysed the functional characteristics of subfossil communities; EJ led the writing of the manuscript. All authors gave final approval for publication.

*Corresponding author; e-mail: e.jablonska@uw.edu.pl start of fen development were correlated with the thickness of subsequently accumulated rich fen peat. RFSI declined in fens approaching change into another mire type, regardless whether it was shifting into bog, forest or eutrophic reeds. RFSI remained comparatively high and stable in three rich fens, which have not terminated naturally until present times. By applying PFT analysis to macrofossil data, we demonstrated that fens may undergo a gradual autogenic process, which lowers the ecosystem's resistance and enhances shifts to other mire types. Long-lasting rich fens, documented by deep peat deposits, are rare. Because autogenic processes tend to alleviate stress in fens, high levels of stress are needed at initial stages of rich fen development to enable its long persistence and continuous peat accumulation.

Key words: ecophysiological stress; ecosystem engineers; ecosystem shift; plant macrofossils; peat deposits; rich fen vegetation succession; tree and shrub encroachment; waterlogging.

\section{HighLIGHTS}

- Rich fen stability is controlled by plant stress caused by waterlogging. 
- Rich fens with initially higher levels of plant stress produce thicker layers of peat.

- Plant functional traits indicate that stress level declines in rich fens approaching shift to other mire types.

\section{INTRODUCTION}

Rich fens are mires (that is, peat-forming wetlands) supplied with groundwater enriched with base ions (Joosten and others 2017). Although the concept of rich fens may include mires from a range of trophic conditions (Wheeler and Proctor 2000), many authors limit it to mesotrophic ecosystems, that host low-productive, nutrient-limited vegetation dominated by low sedges and brown mosses (compare Hájek and others 2006 and references therein). Low productivity is a natural feature of mires, in which part of primary production becomes buried in peat, whereas nutrient influx from outside is absent or very limited. In the present study, we focus on this mesotrophic wing of rich fens, aiming to understand the mechanisms of their stability and shifts to other mire types. Mesotrophic rich fens developing during the Holocene were in some sites displaced in course of succession by bogs or poor fens (for example, Lamentowicz and others 2008), alder forests (for example, Marek 1965) or reed beds or aquatic systems dominated by submerged macrophytes (for example, Michaelis 2002). In some places, rich fens persisted for millennia and until the present (for example, Michaelis 2002; Jabłońska and others 2014; Hájková and others 2015). They are, however, increasingly vanishing, due to large-scale drainage for agriculture and forestry, and regional hydrological alterations (van Diggelen and others 2006). In result, many specialist fen species are on the verge of extinction (for example, Bedford and Godwin 2003; Rehell and Virtanen 2016), while fens have turned from carbon-accumulating systems into significant sources of carbon to the atmosphere (Kotowski and others 2016). To avoid further losses, external disturbing forces need to be eliminated in remaining rich fen systems, whereas the drained ones should be restored, preferably back into stable peat-forming mires (Kotowski and others 2016). However, despite the fact that rich fens are in the focus of conservation and restoration ecologists (see Lamers and others (2015) and Kotowski and others (2016) for references), the effectiveness of their restoration is limited (Klimkowska and others 2019). To learn how to restore degraded rich fens into stable and functional systems, we need to better understand preconditions of stability and instability (ecosystem shifts) in the natural ones.

Ecosystem shifts in mires may be extrinsic (typically associated with allogenic influences, for example, climate change or anthropogenic alteration of catchment hydrology, for example, Hájková and others (2012); Jamrichová and others (2014)) or intrinsic [caused by autogenic factors, that is, related to vegetation succession, for example, progressive accumulation of peat and raising of the plant root zone above the influence of groundwater, for example Kulczyński (1949), Zobel (1988), Williams and others (2011)]. Autogenic factors are in fact 'ecosystem engineer' species (Jones and others 1994) with traits which may drive intrinsic shifts in mires through positive feedbacks (Waddington and others 2015). Allogenic and autogenic factors may also interact, when ecosystem engineers respond to extrinsic changes, thereby amplifying the shift (Singer and others 1996; Magyari and others 2001; Granath and others 2010; Morris and others 2015).

One example of ecosystem engineers is hummock-forming bryophytes. Following acidification of a rich fen (for example, due to partial displacement of groundwater by rainwater), they may foster a further drop of $\mathrm{pH}$ due to active cation exchange (Clymo (1966) for sphagna, Soudzilovskaia and others (2010) for brown mosses), rainwater retention within hummocks (Vicherová and others 2017) and release of organic acids (van Breemen 1995; Siegel and others 2006). In effect, hummock mosses (which are intolerant to calcium, compare Vicherová and others (2015)) are benefited over hollow mosses. In addition, a further expanse of sphagna may be enhanced by capturing $\mathrm{CO}_{2}$ released from bicarbonates in water below the hummocks due to acidification (Harpenslager and others 2015) and their effective nitrogen fixation (Fritz and others 2014).

Another group of mire ecosystem engineers are trees and shrubs, which may lower water saturation in surface peat layers due to enhanced evapotranspiration (Grygoruk and others 2014), thereby facilitating establishment of new trees. Due to the lowered water saturation in surface peat, more oxygen is available for plant roots as well as ectomycorrhizal fungi. Decomposing microorganisms benefit from oxygen availability, enhancing peat mineralization and nutrient availability, which may further stimulate trees growth (Succow and Joosten 2001). Also, tussock-forming sedges have been considered ecosystem engineers (Peach and Zedler 2006) because they can be used as dry 
microhabitats by non-wetland species, including phanerophytes and their mycorrhizal associates.

Ecosystem engineers can be kept in check by stress factors [Grime 1977; also named habitat filters (Keddy 2017)], to which they are intolerant. In rich fens, waterlogging of peat with base-rich groundwater induces plant stress in several ways. Firstly, reduced forms of calcium $\left(\mathrm{Ca}^{2+}\right)$, iron $\left(\mathrm{Fe}^{2+}\right)$, ammonia $\left(\mathrm{NH}_{4}{ }^{+}\right)$or manganese $\left(\mathrm{Mn}^{2+}\right)$ are toxic for sphagna, in contrast to calcium-tolerant rich fen mosses, such as Hamatocaulis vernicosus and Scorpidium scorpioides (Vicherová and others 2015). Secondly, waterlogging limits mineralization of organic matter, causing nutrient limitation stress. Thirdly, anoxia of the root zone keeps out non-aerenchymic plants and obligatorily mycorrhizal species (Peat and Fitter 1993; Hempel and others 2013), including trees, thereby disabling a shift into forests. Field observations from Rospuda Fen in Poland show that a rich fen with high level of the mentioned stresses caused by very stable water table can persist for millennia avoiding shifts to other mire types, in contrast to a dynamically changing neighbouring system with less stable hydrological conditions (Jabłońska and others 2014). Yet, because of rarity of undisturbed fen systems, it is difficult to assess whether the control of rich fen stability by stress factors is a general rule. In the present study, we aim to assess this based on palaeoecological data.

We hypothesize that alleviation of plant stress preceded past shifts of rich fens into other mire types. To check this hypothesis, we analysed plant functional traits (PFTs) spectra of subfossil plant communities, dating back long before humans significantly impacted the landscape. We chose PFTs which may indicate the intensity of the fen stressors described above (compare Table 1). Further, based on the palaeoecological evidence, we propose a PFT-based indicator that can help reconstruct ecosystem's level of plant stress (Douma and others 2012). This approach allows comparisons of systems with a different response to the stress and may help to predict ecosystem shifts in contemporary mires. An establishment of such tools forecasting ecosystem shifts has been recognized as a challenge of global change ecology (Williams and others 2011).

\section{MeTHODS}

\section{Collection of Rich Fen Macrofossil Profiles From Literature}

We compiled a database of 52 peat profiles with rich fen species present and bryophytes determined
(Table 1 in Appendix 1, map in Appendix 1, Appendix 2) and digitized all data from tables and diagrams. A single vegetation sample in this database corresponds to one peat sample analysed for macrofossils and individually displayed on a macrofossil diagram/table. The interval between samples in a peat core varied between studies from 5 to $30 \mathrm{~cm}$. The median interval was $10 \mathrm{~cm}$. Plant macrofossils were described with taxon names of the lowest taxonomic rank available. When hierarchic inclusive taxa were listed in a vegetation sample, for example Carex sp. and Carex rostrata, we treated them as separate taxa, assuming that a macrofossil not recognized as a separate species identifiable in a profile belongs potentially to another species. Taxa were classified as either present non-dominant or dominants. Dominants were those taxa, the amount of which (number of countable remains/volume) clearly exceeded the amount of each other taxon in a sample. Zero to five dominants were chosen per sample.

All digitized samples of subfossil plant communities were inspected for meeting jointly three criteria of rich fen, that is, (1) presence of at least one of rich fen moss species, (2) non-dominance of trees, bog/poor fen specialists, reed and aquatic plants, and (3) the number of taxa mentioned in \#2 not exceeding the number of fen taxa (see Appendix 1 for details). Thirty-nine profiles met these criteria with at least one vegetation sample. In a preliminary analysis, we found that this data set was biased due to altitude (Appendix 3) and removed upland samples (7 profiles) from further analysis. This allowed for a better homogenization of the data set and elimination of additional impact of climate variation due to altitude. The resulting data set contains 32 profiles with rich fen sections from lowland mires (located between 0 and $300 \mathrm{~m}$ a.s.l.) (Table 1 in Appendix 1). In 13 lowland profiles for which radiocarbon dating was provided within rich fen sections, we checked the relationship between age and thickness of these sections and found a significant positive linear correlation. Upland fens were outliers from this relationship-compare Appendix 3.

\section{Plant Functional Traits}

We included 13 PFTs, which may indicate the intensity of anoxia and/or nutrient stresses (Table 1, extended version in Appendix 4). The rate of yearly clonal spread (CS), that is, the increment of clonal growth organ in the horizontal direction, was converted into two binary traits, CS small and CS large, as suggested by Weiher and others (1999). 
Table 1. Plant Functional Traits Analysed

\begin{tabular}{|c|c|c|c|}
\hline & Trait & Sources & Hypothesized response to fen stress conditions \\
\hline BM & $\begin{array}{l}\text { Brown mosses } \\
\text { (non-Sphagnum } \\
\text { mosses) }\end{array}$ & Own assessment & $\begin{array}{l}\uparrow_{\text {AN }} \text { main peat-formers, indicators of low compe- } \\
\text { tition for light (high } N \text { stress) and stable water } \\
\text { level of groundwater origin, can tolerate calcium }\end{array}$ \\
\hline $\mathrm{SPH}$ & Sphagna & Own assessment & $\begin{array}{l}\downarrow_{A} \text { may increase with lowering groundwater feed- } \\
\text { ing, indicating decrease in } A \text { and decrease in } \\
\text { calcium toxicity }\end{array}$ \\
\hline PHA & $\begin{array}{l}\text { Phanerophytes } \\
\text { (trees and } \\
\text { shrubs) }\end{array}$ & Own assessment & $\begin{array}{l}\downarrow_{A} \text { impeded in mires by } A \text {, presumably due to } \\
\text { suppressed ectomycorrhiza; may further trigger } \\
\text { drainage due to increased evapotranspiration }\end{array}$ \\
\hline HF & $\begin{array}{l}\text { Hummock/tussock- } \\
\text { forming species }\end{array}$ & $\begin{array}{l}\text { Own classification, see } \\
\text { Appendix } 4\end{array}$ & $\begin{array}{l}\downarrow_{A} \text { hummocks offer drier safe sites for non-wetland } \\
\text { plants, may enhance establishment of trees and } \\
\text { other competitive species }\end{array}$ \\
\hline EL & $\begin{array}{l}\text { Ellenberg moisture } \\
\text { value F }\end{array}$ & Ellenberg and others (1991) & $\begin{array}{l}\uparrow_{A} \text { high EL indicates the presence of adaptations to } \\
A \text { and flooding, decreases with intensifying } \\
\text { drainage }\end{array}$ \\
\hline $\mathrm{CH}$ & Canopy height $(\mathrm{m})$ & TRY $^{a}$; Rutkowski (2012) & $\begin{array}{l}\downarrow_{N} \text { high } \mathrm{CH} \text { indicates high competition for light } \\
\text { (low } N \text { stress); high } \mathrm{CH} \text { may also be attributed to } \\
\text { plant reaction to flooding, as emergent species } \\
\text { grow tall to stay above the water level, however, } \\
\text { only if nutrients are sufficiently available }\end{array}$ \\
\hline $\begin{array}{l}\text { CS } \\
\text { sm- } \\
\text { all }\end{array}$ & $\begin{array}{l}\text { Yearly clonal } \\
\text { spread present } \\
\text { but }<1 \mathrm{~cm}\end{array}$ & $\begin{array}{l}\text { CLOPLA (Klimešová and de } \\
\text { Bello 2009) }\end{array}$ & $\begin{array}{l}\downarrow_{A} \text { in wetlands species with CS small create tus- } \\
\text { socks or swards, providing stable shelters ele- } \\
\text { vated above the groundwater table, which may } \\
\text { enhance establishment of trees and other species } \\
\text { intolerant to } A\end{array}$ \\
\hline $\begin{array}{l}\text { CS } \\
\text { lar- } \\
\text { ge }\end{array}$ & $\begin{array}{l}\text { Yearly clonal } \\
\text { spread }>1 \mathrm{~cm}\end{array}$ & & $\begin{array}{l}\uparrow_{A} \downarrow_{N} \text { CS large is frequent in wetland dominants, } \\
\text { vegetative propagation is favoured over genera- } \\
\text { tive reproduction under } A \text {; CS large may indicate } \\
\text { extremely productive sites where vegetative } \\
\text { propagation is the only possible because of light } \\
\text { deficiency for germination }\end{array}$ \\
\hline SM & Diaspore mass (mg) & $\mathrm{TRY}^{\mathrm{a}}$; own assessment & $\begin{array}{l}\downarrow_{N} \text { indicates competition for light: large-seeded } \\
\text { plants better germinate in dark and produce } \\
\text { larger seedlings; within rich fens may decrease } \\
\text { with growing } N \text { stress (excluding extremely } \\
\text { productive sites dominated by long-distance } \\
\text { colonizers, for example, Typha, Phragmites) }\end{array}$ \\
\hline SLA & $\begin{array}{l}\text { Specific leaf area } \\
\quad\left(\mathrm{mm}^{2} \mathrm{mg}^{-1}\right)\end{array}$ & $\mathrm{TRY}^{\mathrm{a}}$ & $\begin{array}{l}\downarrow_{\text {AN }} \text { species with high SLA have high photosyn- } \\
\text { thesis investments and are often ruderals or } \\
\text { competitors but rarely stress tolerators; in wet- } \\
\text { lands SLA decreases with increasing wetness and } \\
\text { low SLA may be an adaptation to avoid uptake of } \\
\text { toxic forms of reduced minerals via reduced } \\
\text { evapotranspiration }\end{array}$ \\
\hline LDMC & $\begin{array}{l}\text { Leaf dry matter } \\
\text { content }\left(\mathrm{g} \mathrm{g}^{-1}\right)\end{array}$ & LEDA (Kleyer and others 2008) & $\begin{array}{l}\uparrow_{\text {AN }} \text { high LDMC correspond with conservative } \\
\text { nutrient strategy indicating both } N \text { stress and } A\end{array}$ \\
\hline $\mathrm{Ob}-\mathrm{M}$ & $\begin{array}{l}\text { Obligatory mycor- } \\
\text { rhizal species }\end{array}$ & $\begin{array}{l}\text { MycoFlor (Hempel and others 2013), } \\
\text { Akhmetzhanova and others (2012), }\end{array}$ & $\begin{array}{l}\downarrow_{A} \uparrow_{N} \text { Ob-M may be attributed to the presence of } N \\
\text { stress, impeded by } A\end{array}$ \\
\hline $\begin{array}{c}\text { Non- } \\
\text { M }\end{array}$ & $\begin{array}{l}\text { Non-mycorrhizal } \\
\text { species }\end{array}$ & Veselkin, and others (2014) & $\uparrow_{A}$ indicators of wet conditions $(A)$ \\
\hline
\end{tabular}

Arrows indicate positive $(\uparrow)$ or negative $(\downarrow)$ hypothesized relationship with anoxia $(A)$ and nutrient stress (N). (See Appendix 4 for an extended version of the table.) ${ }^{a}$ TRY Global Plant Traits Database (Kattge and others (2011a); main data sources: Cornelissen and others (1996, 2003, 2004), Ordonez and others (2010), Kattge and others (2011b), Dainese and Bragazza (2012), Royal Botanical Gardens KEW; a list of further data sources, from which in total less than $5 \%$ of data were derived, is provided in Appendix 4). 
Two analysed types of mycorrhizal associations (Ob-M and Non-M) were defined, according to Hempel and others (2013) and Moora (2014). Each mycorrhizal type was treated as a binary trait; facultative mycorrhizal species were given 0 in both categories.

In the case of the identification of taxa at a taxonomical level higher than species (for example, Carex sp., Pteridophyta) or species with missing trait values in the mentioned sources, trait values of taxonomical relatives growing also in mires were assigned based on expert knowledge. Taxa identified to the family level were discarded from the analysis of the mycorrhizal status, with the exception of Ericaceae, which were classified as Ob-M (for example, Hempel and others (2013)).

\section{Data Analysis}

All the 32 profiles with rich fen sections from lowland mires were analysed for the thickness of rich fen sections and the direction of their changes. Further, we calculated community-weighted means (CWM) of traits for all vegetation samples, giving a weight 10 for the dominant taxa and 1 for the remaining taxa.

In a subset of 12 profiles, rich fen sections were at least $1 \mathrm{~m}$ long, allowing for regression analyses of PFT changes. To explore whether CWMs of stressrelated PFTs within the rich fen phases formed directional trends leading to-or indicating-a shift in mire vegetation, we constructed mixed effect models including nine profiles in which rich fen phase finished in the past. (Depth of rich fen end was at least $90 \mathrm{~cm}$-Table 1 in Appendix 1.) We used the distance (measured in $\mathrm{cm}$ ) of a vegetation sample to the position of a vegetation shift in the peat profile (that is, the first non-rich fen sample above a rich fen section within a peat core) as an independent variable. The variable, further referred to as 'distance to rich fen finish', has negative values for samples lying in the peat core below the shift and positive values for samples above the shift; the first non-rich fen sample above the rich fen section within a peat core has value zero. Vegetation samples were grouped by their profile, and a model with a random intercept and a slope was used. We used the Gaussian distribution for quantitative traits (CH, SLA, SM and EL) and binomial distribution for the traits with CWMs within a 0-1 range (SPH, PHA, HF, CS small, CS large, LDMC, $\mathrm{Ob}-\mathrm{M}$ and Non-M). All models were calculated using glmmPQL function in MASS package in $\mathrm{R}$ (Venables and Ripley 2002). The traits, which were significantly related to the distance to rich fen fin- ish according to the above-described models, were then aggregated as a rich fen stress indicator (RFSI), and the relation of RFSI itself to the distance to rich fen finish was checked. Although RFSI values were within 0-1 range, the relationship between RFSI and the distance to the rich fen end was analysed using glmm with the Gaussian distribution and a simple linear regression, because RFSI values were between 0.3 and 0.8 and thus located in the middle (linear) section of the sigmoidal distribution curve. Finally, we calculated also the relation of RFSI to the distance to rich fen finish for three rich fen mires that have persisted to the present or terminated due to a recent human impact; in the latter case, we excluded the uppermost samples of degraded peat from further analysis.

In a subset of 20 rich fen sections, including at least three samples classified as rich fen, needed to calculate a median value, forming a 30-50-cm-long continuous section, we checked the relationship between median RFSI of this lowermost section and the length of the whole rich fen section, expressed as a difference between the first non-rich fen sample above the rich fen finish in a profile and the uppermost vegetation sample in the lowermost 30-50 cm section ('distance to rich fen finish').

\section{RESUltS}

The analysis of 32 profiles showed that most peat profiles included only one rich fen section and the length of the longest rich fen section in a profile, as well as the summary length of rich fen sections, rarely exceeded $200 \mathrm{~cm}$ (Figure 1 in Appendix 5). The majority of rich fen sections did not exceed $50 \mathrm{~cm}$. When shifts occurred, they led equally often towards bogs, forests and reed beds. The majority of rich fen sections start not deeper than $300 \mathrm{~cm}$; only a few rich fen deposits begin at deeper layers (Figure 1).

Out of nine profiles analysed for PFT trends, three changed into bogs or poor fens, another three into fen woodlands and the remaining three into reeds or tall sedge beds. The analysis of PFTs in nine profiles revealed that CWM values for $\mathrm{HF}$, CS small and $\mathrm{CH}$ increased and CWM values for Non-M decreased during rich fen development (Table 2). By analysing rich fen time series together with the peat samples directly following a shift, we found increasing CWM values for PHA and decreasing CWM values for BM.

We assumed that the shares of Non-M and BM (both CWMs decreasing during mire development) are positively related to the level of ecophysiological stress and thus positively related to rich fen 

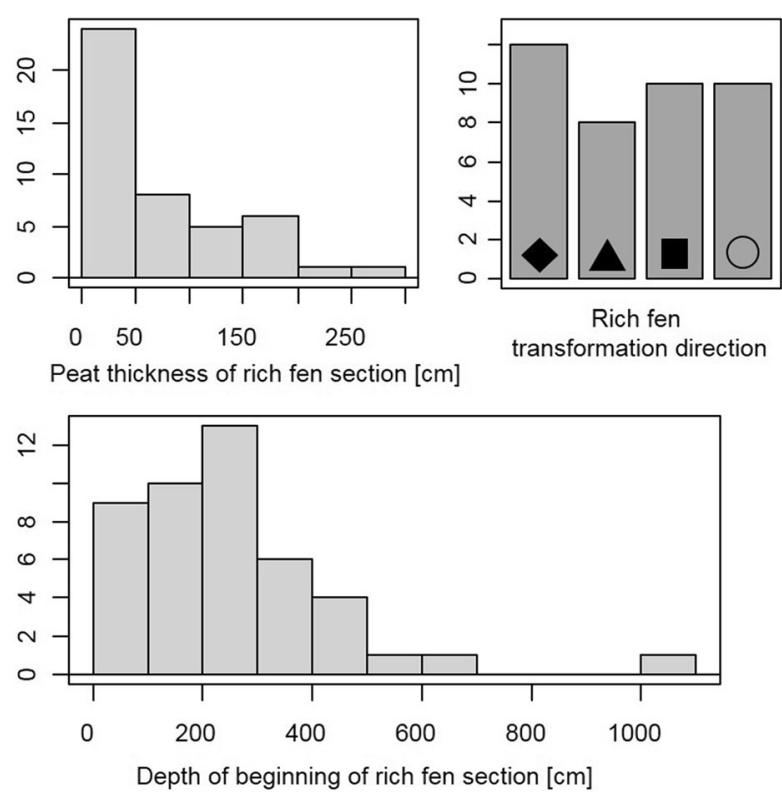

Figure 1. Frequency of rich fen sections $(n=45)$ according to (1) specific peat thickness, (2) specific transformation direction (triangle-into poor fen or bog, diamond-into fen woodlands, square-into reeds and tall sedges, circle-rich fens persisting until now or finished recently due to drainage), and (3) specific initial depth.

stability, whereas the shares of HF, CS small, PHA and $\mathrm{CH}$ (all CWMs increasing during mire development) are negatively related to the level of stress and, similarly, negatively related to rich fen stability (compare Table 1). On the basis of this assumption, we calculated an additive rich fen stress indicator (RFSI) for each vegetation sample (the higher the RFSI value, the more stressed and thus more stable the fen) (equation 1):

$$
\begin{aligned}
\mathrm{RFSI} & =\left(\mathrm{CWM}_{\mathrm{Non}-\mathrm{M}}+\mathrm{CWM}_{\mathrm{BM}}+\left(1-\mathrm{CWM}_{\mathrm{HF}}\right)\right. \\
& +\left(1-\mathrm{CWM}_{\mathrm{CS} \text { small }}\right)+\left(1-\mathrm{CWM}_{\mathrm{CH}} / 2.75\right) \\
& \left.+\left(1-\mathrm{CWM}_{\mathrm{PHA}}\right)\right) / 6
\end{aligned}
$$

To obtain RFSI values ranging from 0 to 1 , CWM of canopy height was standardized for each vege- tation sample to $0-1$ range, by dividing all values by the highest $\mathrm{CH}$ among the species in our data set $(2.75 \mathrm{~m})$.

RFSI was then confirmed to decrease in rich fen time series, which gave the basis for its calculation (Figure 2). RFSI was more or less constant or even increasing for those three rich fens, which had not terminated until the present times (Figure 3). They are characterized by quite high stress level, with RFSI fluctuating between 0.6 and 0.8 (Figure 3), whereas it dropped below 0.6 in those fens that abruptly changed to other ecosystems (Figure 2).

Analysing RFSI in 20 lowermost rich fen sections, we found that it was significantly negatively related to the distance to the rich fen finish (Figure 4).

\section{Discussion}

In our research hypothesis, we proposed that ecosystem shifts in rich fens are preceded by decreases in stress intensity, which facilitates ecosystem engineer species and enhances ecosystem shifts. Indeed, by constructing a composite indicator based on stress-related functional traits, we were able to support this hypothesis, indicating that stress intensity decreased in most of the long-lasting mesotrophic rich fens that underwent a shift to another mire vegetation type. We interpret the decreasing stress as an autogenic cumulative process related to biotic feedbacks by ecosystem engineer species. We also found that such autogenic cumulative changes were absent in rich fens which produced very deep deposits, probably indicating a continuous peat accumulation over thousands of years until now. This finding suggests that under certain circumstances rich fens can be long-lasting and very stable ecosystems. However, as most of the profiles have not been dated, we have to consider that the thicker peat produced by fens with higher stress levels may also result from higher peat accumulation rates under such conditions and not from longer periods of accumulation, or that both explanations are true.

Table 2. The 95\% Confidence Intervals for Average Change in Functional Traits CWM and Rich Fen Stress Index (RFSI) over 5-cm-Thick Peat Deposit (That is, During Rich Fen Development Lasting on Average about 100 Years), Calculated Over the Nine Rich Fens Which Finished in the Past

\begin{tabular}{llllll}
\hline trait CWM & HF $^{\mathrm{a}}$ & CS small $^{\mathrm{a}}$ & $\mathrm{CH}(\mathrm{mm})$ & Non-M & RFSI \\
\hline $95 \%$ CI for average change $/ 5 \mathrm{~cm}$ & $0.03-0.09$ & $0.02-0.06$ & $1-9$ & -0.09 to -0.01 & -0.0038 to -0.0002
\end{tabular}

Only the results for glmm models for rich fen time series significant at 0.05 probability level and with $95 \%$ CI for average change not covering 0 are shown 


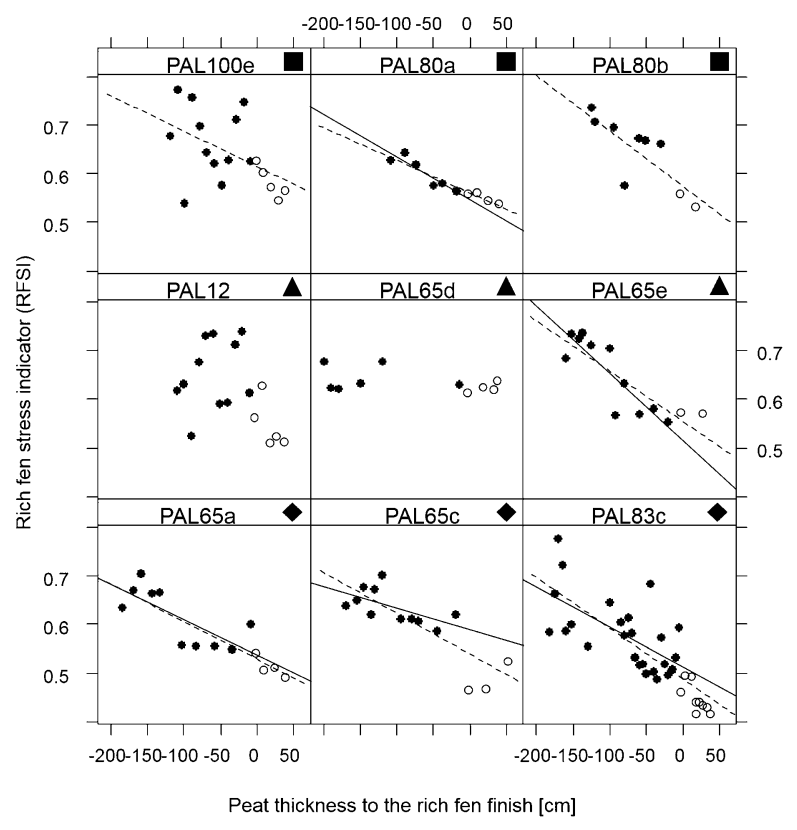

Figure 2. Rich fen stress indicator (RFSI) for the rich fens which finished in the past. The horizontal axis represents the distance to the rich fen finish $(\mathrm{cm})$ expressed as a difference between peat depth of the first non-rich fen vegetation sample above the rich fen finish in a profile and peat depth of a separate vegetation sample -0 represents the end of rich fen. Rich fen transformation direction: triangle-into poor fen or bog, diamond-into fen woodlands, square-into reeds and tall sedges. Black dots-rich fen vegetation samples; white dots-non-rich fen vegetation samples up to $50 \mathrm{~cm}$ above the rich fen finish. Solid lines-linear regression lines for black dots; dashed lines-linear regression lines for black and white dots; only lines with regression coefficient significant at 0.05 probability level are shown.

Transitions of rich fens towards bogs or forests could happen as mere effects of autogenic (intrinsic) changes, driven by a gradual expansion of sphagna or trees. On the contrary, the shift to tall helophytes (reed beds, eutrophic tall sedges) seems rather driven by some external factors causing flooding or increased discharge (extrinsic change). Therefore, it may look surprising why a decrease in stress-based RFSI index was found in most of the profiles documenting shifts of rich fens, regardless whether they changed into bogs, forests or semiaquatic/helophyte/reed bed vegetation. Below, we propose an eco-hydrological explanation how the mentioned autogenic mechanism may, through an increased nutrient availability and a lowered hydrological buffering capacity of the peat, reduce fen resilience to both increased and decreased water inflow.
While analysing changes in stress-related PFTs during the development of mires, we noticed an increase in the share of hummock-forming species, species with a small clonal spread, a larger canopy height and a decrease in the share of non-mycorrhizal species (Table 2). We see several non-exclusive mechanisms that may explain coincidence of these trends towards an abrupt change in rich fen systems. First, as a result of the changes mentioned above, an increasingly hummocky habitat develops. Hummock-forming species are considered ecosystem engineers in mires (Jones and others 1994; van Breemen 1995; Granath and others 2010; Hodges and Rapson 2010). With an increasing height and cover of hummocks, a mire becomes increasingly prone to peat mineralization, due to prolonged oxic conditions within hummocks. An increasing $\mathrm{CH}$ may indicate vegetation response to the increase in nutrient availability due to higher peat decomposition rate in drier hummocky habitat, as well as the community response to flooding, as tall species can tolerate it better than small ones (Moor and others 2017). The above explanations are in concert with the decreasing contribution of Non-M species during fen development. On the one hand, drier conditions/microhabitats created by an increase in HF and CS small species may promote root colonization by mycorrhizal fungi that usually respond negatively to anoxia (for example, Miller 2000; Unger and others 2009). These conditions also facilitate encroachment of shrubs and trees which are obligatory or facultative mycorrhizal, and can further facilitate the establishment of mycorrhizal fungal communities (for example, Soudzilovskaia and others 2015). Establishment of tussock species and small shrubs may also enhance hummock mosses by providing them scaffolding (Weber 1902). On the other hand, if rich fen development proceeds towards reed beds, the decrease in the proportion of non-mycorrhizal plants reflects the increase in helophytes such as Phragmites, Typha, Glyceria and Cladium. These helophytes are facultative mycorrhizal, which may be beneficial for them for example, on the floodplains, where high water level fluctuations create alternate conditions enabling and disabling mycorrhiza (Søndergaard and Lægaard 1977; Braendle and Crawford 1999). Rich fen development towards reed beds may be preceded by an autogenic increase in hummockness, resulting in faster peat decomposition and peat compaction. When water level on such a fen rises due to external factors (river flooding or increased recharge for example, due to catchment deforestation or changes in the regional climate), the 


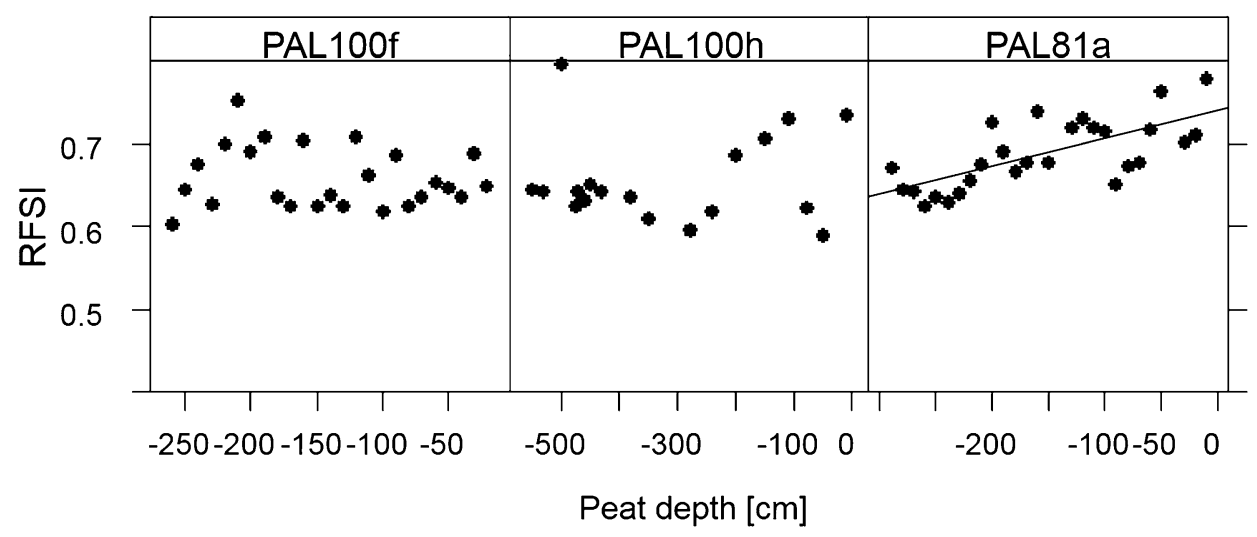

Figure 3. Rich fen stress indicator (RFSI) for three rich fens which are lasting until now (PAL8la) or terminated due to recent drainage (PAL100f, PAL100 h). Solid line-linear regression line for a separate profile; only lines with regression coefficient significant at 0.05 probability level are shown.

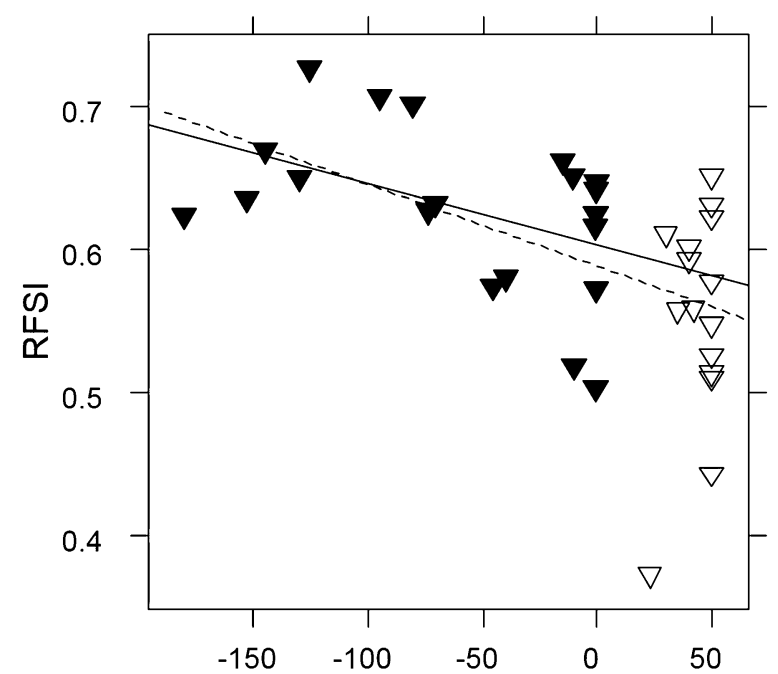

Peat thickness to the rich fen finish [cm]

Figure 4. Median rich fen stress indicator (RFSI) values for c. 50-cm-thick peat sections in relation to the distance to rich fen finish. Black triangles-median RFSI for the lowest part up to $50 \mathrm{~cm}$ thick of each rich fen phase in a profile (excluding sections with less than three vegetation samples and excluding those that did not finish naturally); white triangles-median RFSI for c. 50$\mathrm{cm}$ section of non-rich fen peat lying just above the rich fen phases finish. The horizontal axis represents the distance to the rich fen finish $(\mathrm{cm})$ expressed as a difference between the first non-rich fen sample above the rich fen finish in a profile and the uppermost vegetation sample in the $50-\mathrm{cm}$ section. Solid line-linear regression line for black triangles; dashed line-linear regression line for black and white triangles together; both regressions are significant at 0.05 probability level. Regression coefficient with 95\% CI: solid line: $\quad-0.00043 \pm 0.00041$, dashed line: $-0.00057 \pm 0.00032$. compacted peat is less capable to buffer water level fluctuations [the mire does not swell in response to water table rise (compare Rydin and Jeglum (2013) for 'mire breathing')]. At the same time, compacted peat impedes groundwater through-flow. In effect, the flooding by river waters takes over groundwater seepage. In fact, the expansion of tall helophytes ('reed bed species') may be a combined effect of eutrophication due to peat decomposition and increased input of (eutrophic) surface water (compare Navrátilová and others 2017). Still, however, one should not exclude that the documented transitions to reed beds were fully externally driven and occurred independently from gradual autogenic processes leading to lowered plant stress.

An increased share of tussock sedges, hummock bryophytes or reeds in mesotrophic rich fen plant communities may cause or mark lower stability. Such features characterize many present-day rich fen systems. Our results suggest that such fens may be in their terminal successional stage, probably enhanced by anthropogenic alleviation of environmental stresses through drainage and/or eutrophication. Mowing management can mask symptoms of this shift; but as soon as it is stopped, an ecosystem shift may occur. Rich fens which are still open and devoid of tussock-forming sedges, hummock-forming bryophytes, shrubs and trees, should deserve special attention of conservationists as possibly rare examples of stable, potentially longlasting systems that can be maintained by passive protection. Our results are in line with conclusions of Klimkowska and others (2019) from a crossEuropean meta-analysis of fen restoration projects, that restoration usually fails to re-establish func- 
tional fens because reference levels of plant stress are not achieved (Klimkowska and others 2019).

The rich fen stress indicator that we proposed is a potential predictive tool supporting conservation decisions in fens. However, it should not be regarded as a ready tool for conservationists, before being validated in contemporary fen communities.

\section{ACKNOWLEDGEMENTS}

The research leading to these results has received funding from the Polish-Norwegian Research Programme operated by the National Centre for Research and Development under the Norwegian Financial Mechanism 2009-2014 in the frame of Project Contract No. Pol-Nor/199522/86/2013 (Project MIRACLE). The study was carried out at the Biological and Chemical Research Centre, University of Warsaw, established within the project co-financed by European Union from the European Regional Development Fund under the Operational Programme Innovative Economy 2007-2013. The study has been supported by the TRY initiative on plant traits (http://www.try-db. org). The TRY initiative and database is hosted, developed and maintained by J. Kattge and G. Bönisch (Max Planck Institute for Biogeochemistry, Jena, Germany). TRY is currently supported by DIVERSITAS/Future Earth and the German Centre for Integrative Biodiversity Research (iDiv) HalleJena-Leipzig.

\section{Compliance with Ethical Standards}

Conflict of interest The authors declare that they have no conflict of interest.

\section{OPEN ACCESS}

This article is distributed under the terms of the Creative Commons Attribution 4.0 International License (http://creativecommons.org/licenses/by/4 $.0 /)$, which permits unrestricted use, distribution, and reproduction in any medium, provided you give appropriate credit to the original author(s) and the source, provide a link to the Creative Commons license, and indicate if changes were made.

\section{REFERENCES}

Akhmetzhanova AA, Soudzilovskaia NA, Onipchenko VG, Cornwell WK, Agafonov VA et al. 2012. A rediscovered treasure: mycorrhizal intensity database for 3000 vascular plant species across the former Soviet Union. Ecology 93:68990.
Bedford BL, Godwin KS. 2003. Fens of the United States: distribution, characteristics, and scientific connection versus legal isolation. Wetlands 23:608-29.

Braendle R, Crawford RMM. 1999. Plants as amphibians. Perspectives in Plant Ecology, Evolution and Systematics 2:5678.

Cornelissen JHC, Castro-Díez P, Hunt R. 1996. Seedling growth, allocation and leaf attributes in a wide range of woody plant species and types. Journal of Ecology 84:755-65.

Cornelissen JHC, Cerabolini B, Castro-Díez P, Villar-Salvador P, Montserrat-Martí G et al. 2003. Functional traits of woody plants: correspondence of species rankings between field adults and laboratory-grown seedlings? Journal of Vegetation Science 14:311-22.

Cornelissen JHC, Quested HM, Gwynn-Jones D, van Logtestijn RSP, De Beus MAH et al. 2004. Leaf digestibility and litter decomposability are related in a wide range of subarctic plant species and types. Functional Ecology 18:779-86.

Clymo RS. 1966. Ion exchange in Sphagnum and its relation to bog ecology. Annals of Botany, N.S. 27:309-24.

Dainese M, Bragazza L. 2012. Plant traits across different habitats of the Italian Alps: a comparative analysis between native and alien species. Alpine Botany 122:11-21.

Douma JC, Bardin V, Bartholomeus RP, van Bodegom PM. 2012. Quantifying the functional responses of vegetation to drought and oxygen stress in temperate ecosystems. Functional Ecology 26:1355-65.

Ellenberg H, Weber HE, Dull R, Wirth V, Werner W, Paulissen D. 1991. Zeigerwerte von Pflanzen in Mitteleuropa. Scripta Geobotanica 18:1-248.

Fritz C, Lamers LPM, Riaz M, van den Berg LJL, Elzenga TJTM. 2014. Sphagnum mosses-masters of efficient N-uptake while avoiding intoxication. PLoS ONE 9(1):e79991.

Granath G, Strengbom J, Rydin H. 2010. Rapid ecosystem shifts in peatlands: linking plant physiology and succession. Ecology 91:3047-56.

Grime JP. 1977. Evidence for the existence of three primary strategies in plants and its relevance to ecological and evolutionary theory. The American Naturalist 111:1169-94.

Grygoruk M, Batelaan O, Mirosław-Świątek D, Szatyłowicz J, Okruszko T. 2014. Evapotranspiration of bush encroachments on a temperate mire meadow-A nonlinear function of landscape composition and groundwater flow. Ecological Engineering 73:598-609.

Harpenslager SF, van Dijk G, Kosten S, Roelofs JGM, Smolders AJP, Lamers LPM. 2015. Simultaneous high C fixation and high C emissions in Sphagnum mires. Biogeosciences 12:473949.

Hájek M, Horsák M, Hájková P, Dite D. 2006. Habitat diversity of central European fens in relation to environmental gradients and an effort to standardise fen terminology in ecological studies. Perspectives in Plant Ecology, Evolution and Systematics 8:97-114.

Hájková P, Grootjans A, Lamentowicz M, Rybníčková E, Madaras $M$ et al. 2012. How a Sphagnum fuscum-dominated bog changed into a calcareous fen: the unique Holocene history of a Slovak spring-fed mire. Journal of Quaternary Science 27:233-43.

Hájková P, Horsák M, Hájek M, Jankovská V, Jamrichová E, Moutelíková J. 2015. Using multi-proxy palaeoecology to test a relict status of refugial populations of calcareous-fen species in the Western Carpathians. The Holocene 25:702-15. 
Hempel S, Götzenberger L, Kühn I, Michalski SG, Rillig MC et al. 2013. Mycorrhizas in the Central European flora: relationships with plant life history traits and ecology. Ecology 94:1389-99.

Hodges T, Rapson G. 2010. Is Empodisma minus the ecosystem engineer of the FBT (fen-bog transition zone) in New Zealand? Journal of the Royal Society of New Zealand 40:181207.

Jabłońska E, Falkowski T, Chormański J, Jarzombkowski F, Kłosowski $S$ et al. 2014. Understanding the long term ecosystem stability of a fen mire by analyzing subsurface geology, eco-hydrology and nutrient stoichiometry-case study of the Rospuda Valley (NE Poland). Wetlands 34:81528.

Jamrichová E, Hájková P, Horsák M, Rybníčková E, Lacina A, Hájek M. 2014. Landscape history, calcareous fen development and historical events in the Slovak Eastern Carpathians. Vegetation History and Archaeobotany 23:497-513.

Jones CG, Lawton JH, Shachak M. 1994. Organisms as ecosystem engineers. Oikos 69:373-86.

Joosten H, Moen A, Couwenberg J, Tanneberger F. 2017. Mire diversity in Europe: mire and peatland types. In: Joosten $\mathrm{H}$, Tanneberger F, Moen A, Eds. Mires and peatlands of Europe. Stuttgart: Schweizerbart Science Publishers. p 5-64.

Kattge J, Diaz S, Lavorel S, Prentice IC, Leadley P et al. 201 la. TRY - a global database of plant traits. Global Change Biology 17:2905-35.

Kattge J, Ogle K, Bönisch G, Díaz S, Lavorel S et al. 2011b. A generic structure for plant trait databases. Methods in Ecology and Evolution 2:202-13.

Keddy PA. 2017. Plant ecology. 2nd edn. Cambridge: Cambridge University Press. p 600p.

Kleyer M, Bekker RM, Knevel IC, Bakker JP, Thompson K et al. 2008. The LEDA Traitbase: a database of life-history traits of the Northwest European flora. Journal of Ecology 96:126674.

Klimešová J, de Bello F. 2009. CLO-PLA: the database of clonal and bud bank traits of Central European flora. Journal of Vegetation Science 20:511-16.

Klimkowska A, Goldstein K, Wyszomirski T, Kozub Ł, Wilk MC et al. 2019. Are we restoring functional fens?-The outcomes of restoration projects in fens re-analysed with plant functional traits. PLoS ONE 14:e0215645.

Kotowski W, Ackerman M, Grootjans AP, Klimkowska A, Rößling H, Wheeler B. 2016. Restoration of temperate fens: matching strategies with site potential. Bonn A, Allott $\mathrm{T}$, Evans M, Joosten H, Stoneman R, editors. Peatland Restoration and Ecosystem Services: Science, Policy and Practice. Cambridge: Cambridge University Press. pp 170-91.

Kulczyński S. 1949. Peat bogs of Polesie. Mémoires de l'Académie Polonaise des Sciences et des Lettres. Bulletin des Sciences Naturelles B 15:1-359.

Lamentowicz M, Obremska M, Mitchell EAD. 2008. Autogenic succession, land-use change, and climatic influences on the Holocene development of a kettle-hole mire in Northern Poland. Review of Palaeobotany and Palynology 151:21-40.

Lamers LPM, Vile MA, Grootjans AP, Acreman MC, van Diggelen R et al. 2015. Ecological restoration of rich fens in Europe and North America: from trial and error to an evidence-based approach. Biological Reviews 90:182-203.

Magyari E, Sümegi P, Braun M, Jakab G, Molnár M. 2001. Retarded wetland succession: anthropogenic and climatic signals in a Holocene peat bog profile from north-east Hungary. Journal of Ecology 89:1019-32.

Marek S. 1965. Biologia i stratygrafia torfowisk olszynowych w Polsce. Zeszyty Problemowe Postępów Nauk Rolniczych 57:1303.

Michaelis D. 2002. Die spät- und nacheiszeitliche Entwicklung der natürlichen Vegetation von Durchströmungsmooren in Mecklenburg-Vorpommern am Beispiel der Recknitz. Dissertationes Botanicae 365:1-188.

Miller SP. 2000. Arbuscular mycorrhizal colonization of semiaquatic grasses along a wide hydrologic gradient. New Phytologist 145:145-55.

Moor H, Rydin H, Hylander K, Nilsson MB, Lindborg R, Norberg J. 2017. Towards a trait-based ecology of wetland vegetation. Journal of Ecology 105:1623-35.

Moora M. 2014. Mycorrhizal traits and plant communities: perspectives for integration. Journal of Vegetation Science 25:1126-32.

Morris PJ, Baird AJ, Young DM, Swindles GT. 2015. Untangling climate signals from autogenic changes in long-term peatland development. Geophysical Research Letters 42:10788-97.

Navrátilová J, Hájek M, Navrátil J, Hájková P, Frazier RJ. 2017. Convergence and impoverishment of fen communities in a eutrophicated agricultural landscape of the Czech Republic. Applied Vegetation Science 20:225-35.

Ordonez JC, van Bodegom PM, Witte JPM, Bartholomeus RP, van Dobben HF, Aerts R. 2010. Leaf habit and woodiness regulate different leaf economy traits at a given nutrient supply. Ecology 91:3218-28.

Peach M, Zedler JB. 2006. How tussocks structure sedge meadow vegetation. Wetlands 26:322-35.

Peat HJ, Fitter AH. 1993. The distribution of arbuscular mycorrhizas in the British flora. New Phytologist 125:845-54.

Rehell S, Virtanen R. 2016. Rich-fen bryophytes in past and recent mire vegetation in a successional land uplift area. The Holocene 26:136-46.

Royal Botanical Gardens KEW. Seed Information Database (SID), http://data.kew.org/sid/ accessed May 2014.

Rutkowski L. 2012. Klucz do oznaczania roślin naczyniowych Polski niżowej. Warszawa: Wydawnictwo Naukowe PWN. p $812 \mathrm{p}$.

Rydin H, Jeglum JK. 2013. The Biology of Peatlands. 2nd edn. Oxford: Oxford University Press. p 382p.

Siegel DI, Glaser PH, So J, Janecky DR. 2006. The dynamic balance between organic acids and circumneutral groundwater in a large boreal peat basin. Journal of Hydrology 320:421-31.

Singer DK, Jackson ST, Madsen BJ, Wilcox DA. 1996. Differentiating climatic and successional influences on long-term development of a marsh. Ecology 77:1765-78.

Succow M, Joosten H. 2001. Landschaftsökologische Moorkunde. Stuttgart: Schweizerbart Science Publishers. p 622p.

Soudzilovskaia NA, Cornelissen JHC, During HJ, van Logtestijn RSP, Lang SI, Aerts R. 2010. Similar cation exchange capacities among bryophyte species refute a presumed mechanism of peatland acidification. Ecology 91:2716-26.

Soudzilovskaia NA, van der Heijden MGA, Cornelissen JHC, Makarov MI, Onipchenko VG et al. 2015. Quantitative assessment of the differential impacts of arbuscular and ectomycorrhiza on soil carbon cycling. New Phytologist 208:28093. 
Søndergaard M, Lægaard S. 1977. Vesicular-arbuscular mycorrhiza in some aquatic plants. Nature 268:232-3.

Unger IM, Kennedy AC, Muzika RM. 2009. Flooding effects on soil microbial communities. Applied Soil Ecology 42:1-8.

van Breemen N. 1995. How Sphagnum bogs down other plants. Trends in Ecology, Evolution 10:270-5.

van Diggelen R, Middleton B, Bakker J, Grootjans A, Wassen M. 2006. Fens and floodplains of the temperate zone: present status, threats, conservation and restoration. Applied Vegetation Science 9:157-62.

Venables WN, Ripley BD. 2002. Modern Applied Statistics with S. New York: Springer. p 495p.

Veselkin DV, Konoplenko MA, Betekhtina AA. 2014. Means for soil nutrient uptake in sedges with different ecological strategies. Russian Journal of Ecology 45:547-54.

Vicherová E, Hájek M, Hájek T. 2015. Calcium intolerance of fen mosses: physiological evidence, effects of nutrient availability and successional drivers. Perspectives in Plant Ecology, Evolution and Systematics 17:347-59.

Vicherová E, Hájek M, Šmilauer P, Hájek T. 2017. Sphagnum establishment in alkaline fens: importance of weather and water chemistry. Science of The Total Environment 580:142938.

Waddington JM, Morris PJ, Kettridge N, Granath G, Thompson DK, Moore PA. 2015. Hydrological feedbacks in northern peatlands. Ecohydrology 8:113-27.

Weber C. 1902. Über die Vegetation und Entstehung des Hochmoors von Augstumal im Memeldelta mit vergleichenden Ausblicken auf andere Hochmoore der Erde. Berlin: Paul Parey. p 252p.

Weiher E, van der Werf A, Thompson K, Roderick M, Garnier E, Eriksson O. 1999. Challenging Theophrastus: a common core list of plant traits for functional ecology. Journal of Vegetation Science 10:609-20.

Wheeler BD, Proctor CF. 2000. Ecological gradients, subdivisions and terminology of north-west European mires. Journal of Ecology 88:187-203.

Williams JW, Blois JL, Shuman BN. 2011. Extrinsic and intrinsic forcing of abrupt ecological change: case studies from the late Quaternary. Journal of Ecology 99:664-77.

Zobel M. 1988. Autogenic succession in boreal mires: a review. Folia Geobotanica et Phytotaxonomica 23:417-45. 